\title{
The impact of demographical variables on HRM practices in Saudi Telecom Company: An em- pirical exploration
}

\author{
Nasser S. Al-Kahtani ${ }^{a^{*}}$
}

${ }^{a}$ Associate Professor, Department of Human Resource Management, College of Business Administration, Prince Sattam bin Abdulaziz University, Kingdom of Saudi Arabia

CHRONICLE ABSTRACT

Article history:

Received: November 26, 2017

Received in revised format: November 26, 2017

Accepted: February 7, 2018

Available online:

February 7, 2018

Keywords:

HRM practices

Employees

Public and private telecom com-

pany

Saudi Arabia

\begin{abstract}
Fair HRM practices are indispensable for the success of any company, especially the growing companies. The aim of this exploration is to understand the impact of certain personal characteristics of the employees of Telecommunication Company on HRM practices in the Kingdom of Saudi Arabia. A booklet consisted of HRM practices questionnaires along with personal characteristics blank sheet were used to gather the information of the respondents. A total of 210 sample collected from public and private sector Telecommunication Company existing in the Kingdom. The collected data was analyzed by inferential and descriptive statistics and the results were analyzed. The results revealed that married \& unmarried, public \& private sector, younger \& older, high \& low income and high \& low experienced group of employees differ but in a varied degree on HRM practices in terms of performance appraisal, training and development, security and health, recruitment and selection, intention to stay in the company communication, working conditions, compensation and benefits, job analysis and co-worker relationships. The findings' significances and implications were also elaborated at length and few suggestions were provided that could enhance the fair HRM practices in the telecommunication company in the Kingdom.
\end{abstract}

2018 by the authors; licensee Growing Science, Canada

\section{Introduction}

There is no second deliberation that present era is termed as technological, stressful, self-center and competitive. In such era, Saudi Arabian telecom companies also need to address themselves to come up with the boundaries of the country as well as the outside to maintain the integrity of HRM practices for the effectiveness. Extant investigations have been conducted on the globe but very few in the context of Saudi Arabia to identify the challenges tackling that how fair HRM practices should be used to manage the workforce diversity in the telecommunication company. Indeed, it is necessary to deal the situation in a cordial manner to make their human resources more enthusiastic and develop highest potential in order to accomplish the goals of the organization by using HRM practices in a fair manner. The brand or image and holistic effectiveness of the company depends on how the HRM practices are

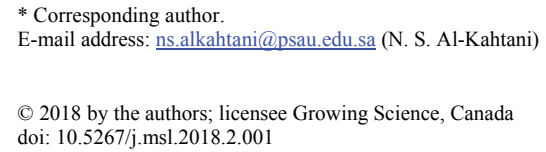


applied in their organization. The success and failure always depends on the development of the human resource and understanding aesthetic of different cultural backgrounds, ways of thinking, knowledge, experience, origins, gender equality, nationalities, mindsets, etc. Kingdom of Saudi Arabia is considered as "under-researched" in the exploration of fair or unfair HRM practices (Al Kahtani et al., 2016). However, various definitions were given by the management experts. One of the researchers, Minbaeva (20005) conceptualized the term HRM practices as "a set of practices used by organization to manage human resource through facilitating the development of competencies that are firm specific, produce complex social relation and generate organizational knowledge to sustain competitive advantages". On the other hand Boxall and Purcell (2011) defined HRM practices as "a set of activities that intend to add value to an organization by managing people related aspects". It is observed from the both definitions that HRM contributes to attract, retain, motivate and develop the employees in order to perform well in the organization through existing fair practices, philosophies and standardize policies.

\section{Review of literature}

The present study tries to review the available literature through papers, theses, books and dissertations pertaining to HRM practices to gain insight about the knowledge and provide ample information to the audiences. The study made an attempt to review the latest studies to show the significance of them in this particular filed on the globe.

Syed and Yan (2012) jointly investigated in their research that job rotation, performance based pay, empowerment, employee participation, grievances handling procedures, merit based promotion and employee participation had positive relationships with job satisfaction. However, most of the studies related to job satisfaction also revealed the relationship with HRM practices such as promotion, advancement training etc. through job satisfaction scale (Allam, 2013; Al Kahtani \& Allam, 2014; Allam, \& Harish, 2010; Ali et al., 2004; Allam \& Reddy, 2007; Al Kahtani \& Allam, 2013). Moreover, HRM practices that help to achieve the performance of organization are recruitment, motivation, compensation, reward system, performance management and appraisal and reward (Islam, 2013).

Hassan (2016) initiated a study among Textile Companies in Pakistan and random sampling technique was used to gather the necessary data. He opined in his research paper that HRM practices pertaining to employee involvement, training, performance appraisal, career planning and compensation had positive influence on the performance of the employees. Razzaq et al. (2017) conducted a study among the employees working in telecom sector in Pakistan and identified the impact of HRM practices on employee commitment. They revealed that HRM practices such as career practice planning and compensation practice had significantly positive impact on employee commitment.

\section{Objectives of the investigation}

On the globe numerous investigations have been carried out by the researchers but there are few investigations conducted on HRM practices in the Kingdom. Hence, the current investigator was taken to explore the understanding of HRM practices existing in telecom companies in Saudi Arabia. Moreover, we aim to explore the impact of certain biographical variables on HRM practices in telecom companies.

\subsection{Hypotheses}

On the basis of the above objectives formulated by the researcher and based on the past review of literature, the following null hypotheses are stated:

$\mathrm{HO}_{1}$ : There is not any significant difference between married and unmarried telecom employees according to various aspects of HRM practices.

$\mathrm{HO}_{2}$ : Public and private telecom sector employees are not different based on the various facets of HRM practices. 
$\mathrm{HO}_{3}$ : Younger and older in age group of telecom employees are not different significantly according to various aspects of HRM practices.

$\mathrm{HO}_{4}$ : There is not any meaningful difference between low and high experienced telecom employees pertaining according to the dimensions of HRM practices.

$\mathrm{HO}_{5}$ : Low and high income group of telecom sector employees are not different based on the various dimensions of HRM practices.

\subsection{Research Methodology}

Sample: The present study consists of 210 randomly selected employees of the public and the private sectors of the telecommunication firms working in the Kingdom who are aged differently and with various job experiences. In the current study all participants were male.

Instrument Used: A booklet consists of HRM practices survey and the demographical blank sheet was used to gather the information from the respondents. HRM practices instruments included ten dimensions where each dimension is rated on the continuum of five-point rating scale with response categories of strongly disagree to strongly agree with a weighted score of 1-5. Moreover, a demographical blank sheet was used to collect the personal characteristics of the employees such as gender, marital status, age, etc.

Data Analysis: Keeping the realm of the objectives of the current investigation, both inferential and descriptive statistics techniques have been used to analyze the data and make the results in a scholastic manner which can add certain values to the HR practitioners.

Procedure and Ethics: The instruments selected for this particular investigation was in English and has been translated to Arabic with the help of expert to maintain the essence of the items of the survey. The purpose to translate the questionnaire was to make it convenient for the respondents to understand it better. The official permission has been taken before the collection of the data. The respondents were briefed about the purpose of the study and informed them to read the instructions very carefully before furnishing the questionnaire. The subjects were assured that their responses will be not disclosed to any higher officials and will be used for academic purposes only.

Table 1

Mean, SD and t-value of social status group of telecom employees on different HRM practices

\begin{tabular}{|c|c|c|c|c|c|}
\hline HRM Practices & $\begin{array}{c}\text { Compared } \\
\text { Groups }\end{array}$ & $\mathrm{N}$ & Mean & $\begin{array}{l}\text { Std. Devia- } \\
\text { tion }\end{array}$ & $\begin{array}{c}\text { t- } \\
\text { value }\end{array}$ \\
\hline \multirow[b]{2}{*}{ Job Analysis } & Married & 141 & 3.65 & .575 & \multirow{2}{*}{$2.579 * *$} \\
\hline & Unmarried & 69 & 3.43 & .557 & \\
\hline \multirow[b]{2}{*}{ Recruitment and Selection } & Married & 141 & 3.56 & .785 & \multirow[b]{2}{*}{.322} \\
\hline & Unmarried & 69 & 3.53 & .584 & \\
\hline \multirow[b]{2}{*}{ Training \& Development } & Married & 141 & 3.52 & .621 & \multirow{2}{*}{$3.069 * *$} \\
\hline & Unmarried & 69 & 3.26 & .504 & \\
\hline \multirow[b]{2}{*}{ Performance Appraisal } & Married & 141 & 3.33 & .775 & \multirow{2}{*}{.293} \\
\hline & Unmarried & 69 & 3.30 & .672 & \\
\hline \multirow[b]{2}{*}{ Compensation \& Benefits } & Married & 141 & 3.62 & .754 & \multirow{2}{*}{$3.026^{* *}$} \\
\hline & Unmarried & 69 & 3.28 & .797 & \\
\hline \multirow[b]{2}{*}{ Working Condition } & Married & 141 & 3.76 & .622 & \multirow{2}{*}{$3.051^{* *}$} \\
\hline & Unmarried & 69 & 3.50 & .443 & \\
\hline \multirow[b]{2}{*}{ Security and Health } & Married & 141 & 3.53 & .809 & \multirow{2}{*}{$3.704 * *$} \\
\hline & Unmarried & 69 & 3.11 & .676 & \\
\hline \multirow[b]{2}{*}{ Communication } & Married & 141 & 3.49 & .911 & \multirow{2}{*}{.255} \\
\hline & Unmarried & 69 & 3.46 & .799 & \\
\hline \multirow[b]{2}{*}{ Co-worker Relation } & Married & 141 & 3.76 & .892 & \multirow{2}{*}{.718} \\
\hline & Unmarried & 69 & 3.67 & .658 & \\
\hline \multirow[b]{2}{*}{ Intention to stay } & Married & 141 & 3.26 & .517 & \multirow{2}{*}{.671} \\
\hline & Unmarried & 69 & 3.30 & .456 & \\
\hline
\end{tabular}


It is observed from the results of Table 1 that the mean scores of the married and unmarried categories of employees working in the telecom companies on different aspects of HRM practices i.e. job analysis (3.65 \& 3.43), training \& development (3.52 \& 3.26), compensation and benefits (3.62 \& 3.28), working conditions $(3.76 \& 3.50)$ and security $\&$ health $(3.53 \& 3.11)$ were found different with the discrepancies in the scores of standard deviation. The t-values were found as $(2.579, \mathrm{P}>.01)$ for the job analysis, $(3.069, \mathrm{P}>.01)$ for the training \& development, $(3.026, \mathrm{P}>.01)$ for the compensation and benefits, $(3.051, \mathrm{P}>.01)$ for the working condition, and $(3.704, \mathrm{P}>.01)$ for the security $\&$ health but the rest of the other aspects were not significant at any level and thereby, the proposed null hypothesis $\left(\mathrm{HO}_{1}\right)$ was not rejected. It is also observed from the table that mean scores of the married employees were higher in all aspects of HRM practices which were also found to be significantly different and this might be because of the maturity, higher level of understanding about the job specifications, job descriptions, value of training \& development, working conditions, etc.

Table 2

Mean, SD and t-value of public and private sector telecom employees on different HRM practices

\begin{tabular}{|c|c|c|c|c|c|}
\hline HRM Practices & Compared Groups & $\mathrm{N}$ & Mean & Std. Deviation & t-value \\
\hline \multirow[b]{2}{*}{ Job Analysis } & Public Sector & 90 & 3.504 & .577 & \multirow{2}{*}{1.63} \\
\hline & Private Sector & 120 & 3.635 & .571 & \\
\hline \multirow[b]{2}{*}{ Recruitment and Selection } & Public Sector & 90 & 3.423 & .604 & \multirow{2}{*}{$2.225^{*}$} \\
\hline & Private Sector & 120 & 3.646 & .791 & \\
\hline \multirow[b]{2}{*}{ Training \& Development } & Public Sector & 90 & 3.433 & .513 & \multirow{2}{*}{.100} \\
\hline & Private Sector & 120 & 3.441 & .655 & \\
\hline \multirow[b]{2}{*}{ Performance Appraisal } & Public Sector & 90 & 3.086 & .781 & \multirow{2}{*}{$4.043 * *$} \\
\hline & Private Sector & 120 & 3.490 & .661 & \\
\hline \multirow[b]{2}{*}{ Compensation \& Benefits } & Public Sector & 90 & 3.359 & .765 & \multirow{2}{*}{$2.356^{* * *}$} \\
\hline & Private Sector & 120 & 3.613 & .782 & \\
\hline \multirow[b]{2}{*}{ Working Condition } & Public Sector & 90 & 3.700 & .507 & \multirow{2}{*}{.616} \\
\hline & Private Sector & 120 & 3.650 & .631 & \\
\hline \multirow[b]{2}{*}{ Security and Health } & Public Sector & 90 & 3.283 & .780 & \multirow{2}{*}{1.689} \\
\hline & Private Sector & 120 & 3.468 & .792 & \\
\hline \multirow[b]{2}{*}{ Communication } & Public Sector & 90 & 3.383 & 1.002 & \multirow{2}{*}{1.370} \\
\hline & Private Sector & 120 & 3.550 & .759 & \\
\hline \multirow[b]{2}{*}{ Co-worker Relation } & Public Sector & 90 & 3.775 & .700 & \multirow{2}{*}{6.54} \\
\hline & Private Sector & 120 & 3.7000 & .903 & \\
\hline \multirow[b]{2}{*}{ Intention to stay } & Public Sector & 90 & 3.180 & .400 & \multirow{2}{*}{$2.333^{*}$} \\
\hline & Private Sector & 120 & 3.340 & .550 & \\
\hline
\end{tabular}

Significant at $* * \mathrm{P}<.01$

Significant at $* \mathrm{P}<.05$

The results of Table 2 indicate that the two groups of employees were working in different sectors on various facets of HRM practices. The results also indicate significant differences on the recruitment \& selection $(\mathrm{t}=2.225, \mathrm{P}>.05)$, the performance appraisal $(\mathrm{t}=4.043, \mathrm{P}>.01)$, the compensation and benefits $(\mathrm{t}=2.356, \mathrm{P}>.01)$ and the intention to stay $(\mathrm{t}=2.333, \mathrm{P}>.05)$. However, the two groups were not differ significantly on other facets of HRM practices, hence, the proposed null hypothesis $\left(\mathrm{HO}_{2}\right)$ was not rejected. It can be said that private sectors had fair practices in the selection \& recruitment, the performance appraisal and the compensation \& benefits as compared to public sector's employees and thereby, the majority of the employees from private sectors were having intention to continue with the ongoing job.

As we can observe from the results of Table 3, no significant difference was found between the younger and the older in age group of employees according to different HRM practices except on the recruitment \& selection $(\mathrm{t}=2.853, \mathrm{P}>.01)$, the training \& development $(\mathrm{t}=2.205, \mathrm{P}>.05)$, and the intention to stay $(\mathrm{t}=2.251, \mathrm{P}>.05)$ but majority of other practices were not significant at any level and thereby, the proposed null hypothesis (HO3) was not rejected. The result can be explained that younger group of 
employees believe that the practices were fair in the recruitment \& selection and the training \& development practices. The mean score showed higher among older employees for the case of intention to stay practice indicates older employees intended to continue with the present job due to loyalty and satisfactions (Allam \& Harish, 2010; Al Kahtani et al., 2016; Allam \& Habtemariam, 2009; Al Kahtani \& Allam, 2014).

Table 3

Mean, SD and t-value of younger and older age groups of telecom employees for HRM practices

\begin{tabular}{|c|c|c|c|c|c|}
\hline HRM Practices & Compared Groups & $\mathrm{N}$ & Mean & Std. Deviation & t-value \\
\hline \multirow[b]{2}{*}{ Job Analysis } & Younger in age & 186 & 3.552 & .582 & \multirow{2}{*}{1.871} \\
\hline & Older in age & 24 & 3.785 & .489 & \\
\hline \multirow[b]{2}{*}{$\begin{array}{l}\text { Recruitment and Selec- } \\
\text { tion }\end{array}$} & Younger in age & 186 & 3.601 & .683 & \multirow[b]{2}{*}{$2.853 * *$} \\
\hline & Older in age & 24 & 3.160 & .912 & \\
\hline \multirow[b]{2}{*}{ Training \& Development } & Younger in age & 186 & 3.470 & .547 & \multirow{2}{*}{$2.205^{*}$} \\
\hline & Older in age & 24 & 3.187 & .869 & \\
\hline \multirow[b]{2}{*}{ Performance Appraisal } & Younger in age & 186 & 3.348 & .667 & \multirow{2}{*}{1.708} \\
\hline & Older in age & 24 & 3.075 & 1.159 & \\
\hline \multirow[b]{2}{*}{ Compensation \& Benefits } & Younger in age & 186 & 3.487 & .722 & \multirow{2}{*}{.891} \\
\hline & Older in age & 24 & 3.638 & 1.165 & \\
\hline \multirow[b]{2}{*}{ Working Condition } & Younger in age & 186 & 3.658 & .459 & \multirow{2}{*}{.891} \\
\hline & Older in age & 24 & 3.770 & 1.163 & \\
\hline \multirow[b]{2}{*}{ Security and Health } & Younger in age & 186 & 3.399 & .699 & \multirow{2}{*}{.504} \\
\hline & Older in age & 24 & 3.312 & 1.319 & \\
\hline \multirow[b]{2}{*}{ Communication } & Younger in age & 186 & 3.484 & .825 & \multirow{2}{*}{.244} \\
\hline & Older in age & 24 & 3.438 & 1.209 & \\
\hline \multirow[b]{2}{*}{ Co-worker Relation } & Younger in age & 186 & 3.741 & .743 & \multirow{2}{*}{.480} \\
\hline & Older in age & 24 & 3.656 & 1.295 & \\
\hline \multirow[b]{2}{*}{ Intention to stay } & Younger in age & 186 & 3.245 & .464 & \multirow{2}{*}{$2.151^{*}$} \\
\hline & Older in age & 24 & 3.475 & .677 & \\
\hline
\end{tabular}

Significant at $* * \mathrm{P}<.01$

Significant at $* \mathrm{P}<.05$

Table 4

Mean, SD and t-value of low and high experienced groups of telecom employees on HRM practices

\begin{tabular}{|c|c|c|c|c|c|}
\hline HRM Practices & $\begin{array}{l}\text { Compared } \\
\text { Groups }\end{array}$ & $\mathrm{N}$ & Mean & $\begin{array}{c}\text { Std. } \\
\text { Deviation }\end{array}$ & t-value \\
\hline \multirow[b]{2}{*}{ Job Analysis } & Low experienced & 87 & 3.492 & .577 & \multirow{2}{*}{1.848} \\
\hline & High experienced & 123 & 3.641 & .5703 & \\
\hline \multirow[b]{2}{*}{ Recruitment and Selection } & Low experienced & 87 & 3.581 & .536 & \multirow{2}{*}{.508} \\
\hline & High experienced & 123 & 3.529 & .833 & \\
\hline \multirow[b]{2}{*}{ Training \& Development } & Low experienced & 87 & 3.333 & .530 & \multirow{2}{*}{$2.157^{*}$} \\
\hline & High experienced & 123 & 3.512 & .632 & \\
\hline \multirow[b]{2}{*}{ Performance Appraisal } & Low experienced & 87 & 3.386 & .624 & \multirow{2}{*}{1.136} \\
\hline & High experienced & 123 & 3.268 & .812 & \\
\hline \multirow[b]{2}{*}{ Compensation \& Benefits } & Low experienced & 87 & 3.409 & .802 & \multirow{2}{*}{1.479} \\
\hline & High experienced & 123 & 3.571 & .766 & \\
\hline \multirow[b]{2}{*}{ Working Condition } & Low experienced & 87 & 3.580 & .458 & \multirow{2}{*}{$1.921^{*}$} \\
\hline & High experienced & 123 & 3.735 & .647 & \\
\hline \multirow[b]{2}{*}{ Security and Health } & Low experienced & 87 & 3.224 & .671 & \multirow{2}{*}{$2.579 * *$} \\
\hline & High experienced & 123 & 3.506 & .848 & \\
\hline \multirow[b]{2}{*}{ Communication } & Low experienced & 87 & 3.517 & .808 & \multirow{2}{*}{.538} \\
\hline & High experienced & 123 & 3.451 & .919 & \\
\hline \multirow[b]{2}{*}{ Co-worker Relation } & Low experienced & 87 & 3.681 & .656 & \multirow[b]{2}{*}{.757} \\
\hline & High experienced & 123 & 3.768 & .9217 & \\
\hline \multirow[b]{2}{*}{ Intention to stay } & Low experienced & 87 & 3.344 & .525 & \multirow[b]{2}{*}{1.810} \\
\hline & High experienced & 123 & 3.219 & .471 & \\
\hline
\end{tabular}


It is observed from Table 4 that the two groups of employees pertaining to experiences in terms of high and low found to be different significantly based on the three facets of HRM practices. The results also revealed that the mean scores on these facets i.e. the training and development $(3.333 \& 3.512)$, the working condition $(3.580 \& 3.735)$ and the security and health (3.224 \& 3.506). The t-values appeared on Table 4 are $(\mathrm{t}=2.157, \mathrm{P}>.05)$ for the training and development, $(1.921, \mathrm{P}>.05)$ for the working condition and (2.579, $\mathrm{P}>.01)$ for the security $\&$ health. Moreover, the low $\&$ high experienced groups were not showing significant differences on other facets of HRM practices, therefore, the proposed null hypothesis $\left(\mathrm{HO}_{4}\right)$ was not rejected. This is because the high experience groups were having higher mean scores on these three facets because of having more knowledge, ability to synthesize the things, etc. compared with the low experience group of telecom sector employees.

Table 5

Mean, SD and t-value of low and high income groups of telecom employees on HRM practices

\begin{tabular}{|c|c|c|c|c|c|}
\hline HRM Practices & $\begin{array}{l}\text { Compared } \\
\text { Groups }\end{array}$ & $\mathrm{N}$ & Mean & Std. Deviation & t-value \\
\hline \multirow[b]{2}{*}{ Job Analysis } & Low income & 93 & 3.433 & .637 & \multirow{2}{*}{$3.359 * *$} \\
\hline & High income & 117 & 3.695 & .496 & \\
\hline \multirow[b]{2}{*}{ Recruitment and Selection } & Low income & 93 & 3.419 & .592 & \multirow{2}{*}{$2.375 * *$} \\
\hline & High income & 117 & 3.655 & .800 & \\
\hline \multirow[b]{2}{*}{ Training \& Development } & Low income & 93 & 3.295 & .531 & \multirow{2}{*}{$3.146^{* *}$} \\
\hline & High income & 117 & 3.551 & .624 & \\
\hline \multirow[b]{2}{*}{ Performance Appraisal } & Low income & 93 & 3.270 & .628 & \multirow{2}{*}{.804} \\
\hline & High income & 117 & 3.353 & .820 & \\
\hline \multirow[b]{2}{*}{ Compensation \& Benefits } & Low income & 93 & 3.358 & .786 & \multirow{2}{*}{$2.442 * *$} \\
\hline & High income & 117 & 3.621 & .764 & \\
\hline \multirow[b]{2}{*}{ Working Condition } & Low income & 93 & 3.543 & .475 & \multirow{2}{*}{$2.907 * *$} \\
\hline & High income & 117 & 3.773 & .635 & \\
\hline \multirow[b]{2}{*}{ Security and Health } & Low income & 93 & 3.137 & .698 & \multirow{2}{*}{$4.288 * *$} \\
\hline & High income & 117 & 3.589 & .805 & \\
\hline \multirow[b]{2}{*}{ Communication } & Low income & 93 & 3.419 & .838 & \multirow{2}{*}{.875} \\
\hline & High income & 117 & 3.526 & .902 & \\
\hline \multirow[b]{2}{*}{ Co-worker Relation } & Low income & 93 & 3.588 & .783 & \multirow{2}{*}{$2.278^{*}$} \\
\hline & High income & 117 & 3.846 & .836 & \\
\hline \multirow[b]{2}{*}{ Intention to stay } & Low income & 93 & 3.367 & .531 & \multirow{2}{*}{$2.536^{* *}$} \\
\hline & High income & 117 & 3.194 & .455 & \\
\hline
\end{tabular}

Significant at $* * \mathrm{P}<.01$

Significant at $* \mathrm{P}<.05$

It is evident from the Table 5 that the two groups of employees having low and high income were different significantly on almost all HRM practices except (performance appraisal \& communication). Furthermore, the results also indicate that the mean scores of high income group were observed higher than their counterparts on all practices of HRM. The tabulated t-values were observed significantly different on job analysis $(\mathrm{t}=3.359, \mathrm{P}>.01)$, recruitment \& selection $(\mathrm{t}=2.375, \mathrm{P}>.01)$, training and development $(\mathrm{t}=3.146, \mathrm{P}>.05)$, compensation \& benefits $(\mathrm{t}=2.442, \mathrm{P}>.01)$, working condition $(\mathrm{t}=2.907, \mathrm{P}>.01)$, security and health $(\mathrm{t}=4.288, \mathrm{P}>.01)$, co-worker relation $(\mathrm{t}=2.278, \mathrm{P}>.05)$ and intention to stay $(\mathrm{t}=2.536, \mathrm{P}>.01)$, respectively. Therefore, the planned hypothesis $\left(\mathrm{H}_{5}\right)$ was partially rejected. The result might be highlighted that two groups believed that practices were slightly different due to variations in the mean scores which indicate that income plays pivotal role in understanding the practices prevailing in the telecom company.

\section{Conclusion}

The current investigation has revealed that the differences were in place between various groups such as age, marital status, income, experience and types of sector of employees who were working in Telecom Company according to various dimensions of HRM practices. Based on findings, the following conclusions have been drawn as: 
* The group of married employees showed significantly higher degree of HRM practices on the job analysis, the training \& development, the compensation and benefits, the working conditions and the security $\&$ health than their counterparts.

* The employees of the private sector telecom company perceived significantly more HRM scores on the recruitment \& selection, the performance appraisal, the compensation and the benefits and intention to stay than the employees of the public sector did.

* A significant differences were observed between the younger and older group of the employees on the basis of HRM practices with regard to the recruitment \& selection, the training \& development and the intention to stay practices.

* The high experienced group of employees showed higher degree of mean scores on the training and development, the working condition and the security and health.

* It was observed that the mean scores of the high income group were higher than their counterparts on all HRM practices in the present investigation.

\section{Suggestions and Limitations}

It is observed from the findings that HRM practices existed in the telecom sector of the Kingdom, but found marginally different between various biographical variables, so there is a need to implement fair HRM practices by the management to enhance the performance of the employees. Unfair HRM practice is corrosive and requires timely corrective measures by the higher officials to make the organization more viable and successful. As noted by the various researchers, satisfaction, timely training $\&$ feedback, financial \& non-financial incentives and other management practices play pivotal role in enriching the commitment and involvement of the employees to perform well (Allam, 2007, 2017). The empathy and sympathy both should go in side by side way so that employees could feel some sense of belongingness and contribute major role in decision making process to build the organization success but HRM practices should be fair.

This particular research initiated only on one type of the employees i.e. telecom company, thereby it is necessary to conduct similar studies in future with more different organizations to have authentic and significant findings. As far as sample is concerned, more sample should be taken in future research with diversified groups. In glimpse, HRM practices are plenty and need to add more practices which can contributes in the process of enhancement of the employees' performance in a planned study.

\section{Acknowledgement}

The authors would like to thank the anonymous referees for constructive comments on earlier version of this paper.

\section{References}

Al Kahtani, N.S. \& Allam, Z. (2013). A comparative study of job burnout, job involvement, locus of control and job satisfaction among banking employees of Saudi Arabia. Life Science Journal, 10(4), 2135-2144.

Al Kahtani, N.S. \& Allam, Z. (2014). The influence of job burnout, involvement and locus of control on job satisfaction: Some explorations from banking sector in Saudi Arabia, New York Science Journal, 7(2), 93-101.

Al Kahtani, N.S., Nawab, A. K., \& Allam, Z. (2016). Unfair HRM practices in the telecom sector in Saudi Arabia: An empirical investigation of selected public and private sector companies. International Journal of Applied Business and Economic Research, 14(10), 6381-6400.

Ali, N., Khan, M.S., \& Allam, Z. (2004). A study on job satisfaction among doctors: Effect of locus of control, sex and marital status. PCTE Journal of Business Management, 1(2), 34-36. 
Allam, Z., \& Habtemariam, R. (2009). Impact of Job Burnout, Age and Marital Status on Job Involvement among Banking Employees in Eritrea. The Nigerian Journal of Guidance and Counseling, 14(1), 28-34

Allam, Z., \& Harish, K.T. (2010). Influence of sociodemographic factors on job burnout and satisfaction among Eritrean medical workers. Nigerian Journal of Psychiatry, 8(1), 43-47.

Allam, Z. \& Reddy, B.S.K. (2007). Effect of gender, marital status and locus of control on job satisfaction-empirical study from textile organisation in Africa. ACMR Journal of Business and Mangement Research, 2(2),57-59.

Allam, Z. (2007). A study of relationship of job anxiety and job burnout with job involvement among bank employees. Management and Labor Studies, 21(1) 30-38.

Allam, Z. (2013). Job anxiety, organizational commitment and job satisfaction: An empirical assessment of supervisors in the state of Eritrea. International Journal of Development and Management Review, 8, 50-62.

Allam, Z. (2017).Intrinsic and extrinsic motivation: An empirical tale of employees look in a job. Research Journal of Applied Sciences, 12(2), 117-124.

Boxall, P. \& Purcell, J. (2011). Strategy and Human Resource Management. $3^{\text {rd }}$ Ed. United Kingdom: Palgrave Macmillan.

Hassan, S. (2016).Impact of HRM practices on employee's performance. International Journal of Academic Research in Accounting, Finance and Management Sciences, 6(1), 15-22.

Islam, M. Z. (2013). What matters for organisational change? Evidence from DEPZ, Bangladesh. $S A$ Journal of Human Resource Management, 11(1), 1-13.

Minbaeva, D.B. (2005).HRM practices and MNC knowledge transfer. Personal Review, 34(1), 125144.

Razzaq, S., Aslam, U., Bagh, T. \& Saddique, S. (2017) .The impact of human resource management practices on employee commitment: Evidences from Pakistan Telecom Sector. International Journal of Academic Research in Business and Social Sciences, 7(7), 649-667.

Syed, N. \& Yan, L.X. (2012). Impact of high performance human resource management practices on employee job satisfaction: Empirical Analysis. Interdisciplinary Journal of Contemporary Research Business, 4(2).318-341.

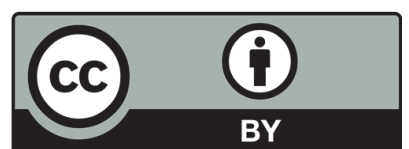

(C) 2018 by the authors; licensee Growing Science, Canada. This is an open access article distributed under the terms and conditions of the Creative Commons Attribution (CC-BY) license (http://creativecommons.org/licenses/by/4.0/). 